\title{
Baş boyun kanserli hastalarda tedavi sonuçları ve prognostik faktörler
}

\author{
Results and prognostic factors in patients with head and neck cancer \\ Ebru Atasever Akkaş, Birsen Yücel, Saadettin Kılıçkap, Nalan Akgül Babacan, \\ Emine Elif Altuntaş
}

Radyasyon Onkolojisi Kliniği (Dr. E. A. Akkaş), Sivas Numune Hastanesi, TR-58040 Sivas, Radyasyon Onkolojisi Anabilim Dalı (Yrd. Doç. Dr. B. Yücel), Tıbbi Onkoloji Bilim Dalı (Doç. Dr. S. Kılıçkap, Yrd. Doç. Dr. N. A. Babacan), Kulak Burun Boğaz Hastalıkları Anabilim Dalı (Yrd. Doç. Dr. E. E. Altuntaş), Cumhuriyet Üniversitesi Tıp Fakültesi TR-58140 Sivas

\begin{abstract}
Özet
Amaç. Merkezimizde takip ve tedavi edilen baş boyun kanseri hastalarında klinikopatolojik özelliklerin, tedavi sonuçlarının ve sağkalımı etkileyen prognostik faktörlerin incelenmesi amaçlanmıştır. Yöntem. 2007-2010 tarihleri arasında merkezimize başvuran ve baş boyun kanseri tanısı ile izlenmekte olan hastalara ait demografik, klinik ve histopatolojik veriler hasta dosya ve hastane kayıtları incelenerek elde edildi. Bulgular. Seksen iki hastaya ait veriler analiz edildi. 72 erkek (\%88) ve 10 kadın (\%12) hasta mevcuttu. Hastaların ortanca yaşı 57 (20-80) idi. En genç hastalar nazofarenks, parahipofarenks ve paranazal sinüs tümörü olan hastalardı. En yaygın malignensi 37 hastada (\%45) bulunan larenks kanseri idi. Elli beş hasta (\%67) Eastern Cooperative Oncology Group 1 idi. En sık evre 51 hasta (\%62) ile lokal ileri evre idi. Tanı anında 60 (\%75) hastada anemi, 30 (\%60) hastada C- reaktif protein yüksekliği, 72 (\%89) hastada kilo kaybı tespit edildi. Yassı hücreli karsinom 69 (\%84) hasta ile en sık izlenen histopatolojik tip idi. On yedi (\%47) hastada perinöral invazyon, $17(\% 47)$ hastada lenfovasküler invazyon, $12(\% 32)$ hastada ekstrakapsüler invazyon tespit edildi. Hastalar arasında en sık izlenen grade 34 (\%42) hasta ile grade II idi. Tüm hastalar için ortanca sağkalım 34 aydı. İki yıllık genel sağkalım oranı erken evre (I-II) hastalarda \%75, lokal ileri hastalarda (III-IVA ve B) \%51 iken, metastatik hastalık varlığında ise ortanca sağkalım 10 ay idi. Eşlik eden hipertansiyon varlığı, performans durumu, kanserin lokalizasyonu ve evresi, T ve $\mathrm{N}$ evresi, radyoterapiye ara verilmesi, C- reaktif protein düzeyi ve anemi sağkalımı belirleyen faktörler idi. Sonuç. Hipertansiyon varlığı, performans durumu, kanserin lokalizasyon ve evresi, $\mathrm{T}$ ve $\mathrm{N}$ evresi, radyoterapiye ara verilmesi, C- reaktif protein düzeyi ve anemi baş boyun kanserli hastalarda sağkalımı etkileyen prognostik faktörler olarak belirlendi.
\end{abstract}

Anahtar sözcükler: Baş boyun kanseri, radyoterapi, kemoterapi, prognoz

\begin{abstract}
Aim. Our aim was to investigate the clinicopathological features, the treatment outcome and the prognostic factors affecting survival in patients with head and neck cancer followed and treated in our center. Methods. The demographic, clinical and the histopathological data of the patients who were admitted to our center between 2007 and 2010 with a diagnosis of head and neck cancer were examined using the medical records. Results. The data from 82 patients were analyzed. There were 72 men (88\%) and 10 women (12\%). The median age of the patients was 57 (20-80) years. The youngest patients had nasopharyngeal, parahypopharyngeal and paranasal sinus tumors. The most commonly encountered malignancy was the laryngeal cancer, which was found in 37 patients (45\%). Fifty-five patients (67\%) were Eastern Cooperative Oncology Group 1. The most common grade was the locally advanced stage with 51 patients (62\%). At time of the diagnosis, $60(75 \%)$ patients had anemia, $30(60 \%)$ patients had an elevated C-reactive protein, and $72(89 \%)$ patients had weight loss. Squamous cell carcinoma, which was seen in $69(84 \%)$ patients, was the most common histological type. Seventeen (47\%) patients had perineural invasion, $17(47 \%)$ patients had lymphovascular invasion, and $12(32 \%)$ patients had extracapsular invasion. Among the patients, the most common grade was grade II, which was found in $34(42 \%)$ patients. The overall median survival was 34 months. The 2 -year survival rate was $75 \%$ for the patients with early-stage (I-II) cancer and $51 \%$ for the patients with locally advanced (III-IVA and B) cancer, the median
\end{abstract}


survival was 10 months in the presence of metastatic disease. The presence of hypertension comorbidity, performance status, location and stage of the cancer, $\mathrm{T}$ and $\mathrm{N}$ stage, interruption of radiation therapy, C-reactive protein levels, and anemia were the factors that determined survival. Conclusion. The presence of hypertension, performance status, location and stage of the cancer, $\mathrm{T}$ and $\mathrm{N}$ stage, interruption of radiation therapy, C-reactive protein levels, and anemia were identified as prognostic factors affecting survival in patients with head and neck cancers.

Keywords: Head and neck cancer, radiotherapy, chemotherapy, prognosis

Geliş tarihi/Received: 27 Eylül 2012; Kabul tarihi/Accepted: 07 Ocak 2013

\section{*İletişim adresi:}

Dr. Ebru Atasever Akkaş, Radyasyon Onkolojisi Kliniği, Sivas Numune Hastanesi, TR-58040 Sivas. E-posta: ebrusse@ mynet.com

\section{Giriş}

Baş boyun kanserleri tüm kanserlerin \%4-5'ini, kanserden ölümlerin ise \%2'sini oluşturmaktadır [1]. Tüm kanserler içinde altıncı sıklıkta, kanser nedenli ölümler arasında yedinci sıklıkta izlenen bir kanser türü olup, özellikle gelişmekte olan ülkelerde insidansı giderek artmaktadır [2]. Türkiye'de ise 2005 İzmir kanser kayıt merkezi verilerine göre tüm kanserlerin \%7,7'sini oluşturmaktadır [3]. Genel olarak baş boyun kanserleri T1 ve T2 tümörlerinde cerrahi rezeksiyon veya radyoterapi tek modalite olarak uygulanır. İki tedavi modalitesi arasındaki seçimi tümörün (lokalizasyon, histopatolojik özellikler) ve hastanın (meslek, genel sağlık durumu, hastanın tercihi) özellikleri belirler. T3 ve T4 tümörlerin tedavisinde cerrahi, kemoterapi ve radyoterapi kombine olarak kullanılır. Cerrahinin uygulanamadığı hastalarda yüksek doz radyoterapi veya kemoradyoterapi uygulanabilir [4]. Baş boyun kanserlerinin lenfatik metastaza olan eğilimleri ve lenfatik metastazın prognozu ve sağkalımı belirleyen en önemli faktörlerden biri olması nedeniyle, baş boyun kanserlerinin büyük çoğunluğunda boynun tedavisi endikedir [4]. Yapılan çalışmalarda; tümör yaygınlığı, histopatolojik özellikler, yaş, cinsiyet, performans durumu, komorbidite, beslenme durumu ve anemi varlığ 1 prognozu belirleyen faktörler olarak belirlenmiştir [5].

Bu çalışmada, 2007-2010 tarihleri arasında merkezimizde tedavi edilen hastaların tedavi sonuçları ve sağkalımı etkileyen prognostik faktörlerin araştırılması amaçlanmıştır.

\section{Gereç ve yöntem}

Cumhuriyet Üniversitesi Tıp Fakültesi Radyasyon Onkolojisi Kliniğine 2007-2010 tarihleri arasında başvuran ve baş boyun kanseri tanısı ile izlenmekte olan 82 hastaya ait demografik, klinik ve histopatolojik veriler hasta dosya ve hastane kayıtları incelenerek elde edildi. Tüm hastalar için İl Nüfus Müdürlüğü'nden izin alınarak kimlik sorgulama sisteminde hastaların yaşayıp yaşamadıkları öğrenilerek kaydedildi. Hastaların performans durumu başvuruda Eastern Cooperative Oncology Group (ECOG) skorlama sistemine göre değerlendirildi. Komorbidite varlığ 1 yönünden kardiyovasküler hastalık, hipertansiyon, diabetes mellitus, kronik böbrek hastalığı, kronik obstrüktif akciğer hastalığ için hemoglobin değerinin $12 \mathrm{~g} / \mathrm{dL}$ 'den düşük olması, C-reaktif protein (CRP) yüksekliği için $5 \mathrm{mg} / \mathrm{L}$ 'den yüksek olması ve kilo kaybı için 1 ayda kilosunun \%10'undan fazlasının kaybedilmesi anlamlı kabul edildi. Hastalık evresi 2002 International Union Against Cancer / American Joint Committee On Cancer (UICC/AJCC) TNM sinıflamasina göre yapıldı [6]. Konvansiyonel fraksiyon ile radyoterapi günde 1,8-2 Gy, haftada 5 fraksiyon, hiperfraksiyon şeması ile radyoterapi günde $2 \mathrm{kez} 1,2 \mathrm{~Gy}$, haftada 10 fraksiyon şeklinde uygulanmıştı. Radyoterapi planlaması 3 boyutlu konformal olarak Eclipse programı ile tedavi ise lineer hızlandırıcıda $6 \mathrm{MV}$ veya $18 \mathrm{MV}$ foton enerjisi ve gerektiğinde uygun elektron enerjisi $(9,12,16$ veya $20 \mathrm{MeV}$ gibi) kullanılarak gerçekleştirilmişti. Eş zamanlı 
kemoradyoterapi uygulanan hastalarda haftalık cisplatin $\left(40 \mathrm{mg} / \mathrm{m}^{2}\right)$ veya haftalık cisplatin $\left(25 \mathrm{mg} / \mathrm{m}^{2}\right)+$ docetaxel $\left(25 \mathrm{mg} / \mathrm{m}^{2}\right)$ rejimleri uygulandi. Tedavi sirasinda haftada bir kez, takiplerde ise 3 ayda bir kez Radiation Therapy Oncology Group / European Organisation for Research and Treatment of Cancer (RTOG/EORTC) kriterlerine göre yan etki değerlendirmesi yapıldı [7].

Tüm veriler SPSS 14.0 veri tabanına yüklendi. Sıklık tablosu yanısıra, veriler ki-kare testi ve Mann-Whitney U testi kullanılarak analiz edildi. Sağkalım analizi için Kaplan-Meier yöntemi kullanıldı. P değerinin < 0,05 olması istatiksel olarak anlamlı kabul edildi. Çalışma öncesinde verilerin toplanması, değerlendirilmesi, analizi ve yorumlanabilmesi için Cumhuriyet Üniversitesi Tıp Fakültesi Etik Kurulundan onay alındı.

\section{Bulgular}

Bu çalışmada 72'si erkek (\%88) ve 10'u kadın (\%12) olmak üzere toplam 82 hastaya ait veriler analiz edildi. Hastaların ortanca yaşı 57 (20-80) idi. Erkeklerde ortanca yaş 58, kadınlarda ortanca yaş 44 olup, cinsiyetler arasında yaş dağılımı yönünden istatistiksel olarak fark bulunmaktaydı. Lokalizasyon açısından tanı yaşı göz önüne alındığında, en genç hastalar nazofarenks, parahipofarenks ve paranazal sinüs tümörü olan hastalardı. Ancak hastalarda lokalizasyona göre yaş bakımından istatistiksel olarak anlamlı fark tespit edilmedi $(\mathrm{p}=0.472)$. Ailede kanser hikayesi $15(\% 18)$, sigara kullanımı 57 (\%70), alkol kulanımı $13(\% 16)$ ve medikal komorbidite 23 (\%28) hastada mevcuttu. Hastalar performans açısından değerlendirildiklerinde 25 (\%31) hasta ECOG 0, 55 (\%67) hasta ECOG 1 idi. Altmış (\%75) hastada anemi, 30 (\%60) hastada CRP yüksekliği ve $72(\% 89)$ hastada kilo kaybı tespit edildi. 72 ( \%88) hasta ile (\%88) en s1k yassı hücreli karsinom saptanırken, 10 (\%12) hastada diğer histopatolojik (mukoepidermoid karsinom, adenoid kistik karsinom, asinik hücreli karsinom ve malign melanom) tipler tespit edildi. 37 hasta (\%45) ile larenks kanseri ve 21 (\%26) hasta ile oral kavite kanseri saptanan malignensilerin büyük kısmını oluşturmakta idi. Hastaların 14'ü (\%17) nazofarenks, 8'i (\%10) parahipofarenks ve paranazal sinüs ve 2'si (\%2) primeri bilinmeyen baş boyun kanserine sahipti. Hastaların 28'i (\%34) erken evrede (Evre I-II), 51'i (\%62) lokal ileri evrede (Evre III-IVA-B), 3'ü (\%4) ise metastatik evrede tanı almıştı. Grade I 24 (\%24), Grade II 34 (\%42) Grade III 24 (\%29) hastada tespit edildi. Hastaların 17'sinde (\%47) perinöral, 17'sinde (\%47) lenfovasküler, 12'sinde (\%32) ekstrakapsüler invazyon pozitifliği tespit edildi. Ortanca tümör çap $3 \mathrm{~cm}(0,3-11)$ iken, ortanca tutulan lenf nodu sayısı 2 (1-11) idi. Hastaların klinikopatolojik ve demografik özellikleri Tablo 1'de görülmektedir.

Hastaların 6'sına (\%7) cerrahi, 33'üne (\%40) cerrahi+radyoterapi/kemoradyoterapi, 16 'sina (\%20) indüksiyon kemoterapi+kemoradyoterapi, 12'sine (\%15) kemoradyoterapi, 11 'ine (\%13) radyoterapi ve 4'üne (\%5) kemoterapi uygulanmıştır.

Hastaların 3'üne (\%4) subtotal larenjektomi, 4'üne (\%5) parsiyel dil eksizyonu, 15'ine (\%18) total larenjektomi, 15'ine (\%18) kitle eksizyonu, 4'üne (\%5) maksillektomi ve 41 'ine (\%50) biyopsi yapılmıştır. Otuz (\% 37) hastaya boyun diseksiyonu yapılmıştır. Boyun disseksiyonu uygulanan hastalardan 15 'ine (\%50) radikal/fonksiyonel tek tarafl,, 15 'ine (\%50) radikal/fonksiyonel bilateral boyun disseksiyonu yapılmıştır.

Hastalar ortanca 16 (1-71) ay takip edildiler. Tüm hastalar için ortanca sağkalım 34 ay ve 2 yıllık sağkalım oranı ise \%58 idi. Lokalizasyona göre sağkalım oranları istatistiksel olarak anlamlı farklılık göstermekteydi $(\mathrm{p}=0,002)$. İki y1llık sağkalım oranları larenks kanserli hastalarda \%62, nazofarenks kanserli hastalarda \%85, parahipofarenks ve paranazal sinüs kanserli hastalarda $\% 25$ ve oral kavite kanserli hastalarda \%52 idi. 2 yıllık sağkalım oranı erken evredeki (I-II) hastalarda \%75 ve lokal ileri hastalık varlığında (III-IVA ve B) \%51 iken, metastatik hastalık varlığında ortanca sağkalım 10 ay idi. Kanserin evresi ile sağkalım arasında istatistiksel olarak anlamlı farklılık bulunmaktaydı $(\mathrm{p}=0,001)$. 
Tek değişkenli analizde, kanserin lokalizasyonu $(p=0,002)$, anemi varlığ $(p=0,024), C R P$ düzeyi $(\mathrm{p}=0,021)$, yan etki nedeniyle radyoterapiye ara verilmesi $(\mathrm{p}=0,029)$, hastanın performans durumu $(p=0,003), T(p=0,012)$ ve $N(p=0,027)$ evresi ve eşlik eden hipertansiyon varlığ $(\mathrm{p}=0,043)$ sağkalımı etkileyen faktörler olarak belirlendi. Cinsiyet $(p=0,721)$, diğer medikal komorbiditeler $(p=0,274)$, ekstrakapsüler invazyon $(p=0,087)$, lenfovasküler invazyon $(p=0,561)$, perinöral invazyon $(p=0,451)$, grade $(p=0,143)$, kemoradyoterapide sisplatine karşı sisplatin+dosetaksel verilmesi $(\mathrm{p}=0,446)$, mukozit gelişimi $(\mathrm{p}=0,081)$ ve kilo kaybı $(\mathrm{p}=0,707)$ sağkalım üzerine istatistiksel olarak anlamlı etkide bulunmamaktaydı. Çok değişkenli analizde anlamlı değişken saptanmadı. Tablo 2'de sağkalımı etkileyen faktörler görülmektedir.

Tablo 1. Baş-boyun kanserli hastaların klinikopatolojik ve demografik özellikleri.

\begin{tabular}{|c|c|c|}
\hline & Hasta sayısı & $\%$ \\
\hline \multicolumn{3}{|l|}{ Hastaya ait özellikler } \\
\hline \multicolumn{3}{|l|}{ Cinsiyet } \\
\hline Erkek & 72 & 88 \\
\hline Kadın & 10 & 12 \\
\hline Ailede kanser hikayesi & 15 & 18 \\
\hline Sigara & 57 & 70 \\
\hline Medikal komorbidite & 23 & 28 \\
\hline \multicolumn{3}{|l|}{ Performans durumu } \\
\hline ECOG 0 & 25 & 31 \\
\hline $\mathrm{ECOG} \geq 1$ & 57 & 67 \\
\hline \multicolumn{3}{|l|}{ Lokalizasyon } \\
\hline Oral kavite & 21 & 26 \\
\hline PHP ve PH & 8 & 10 \\
\hline Nazofarenks & 14 & 17 \\
\hline Larenks & 37 & 45 \\
\hline Primeri bilinmeyen & 2 & 2 \\
\hline \multicolumn{3}{|l|}{ Histopatoloji } \\
\hline Yassı hücreli karsinom & 72 & 88 \\
\hline Diğer & 10 & 12 \\
\hline Perinöral invazyon & 17 & 47 \\
\hline Lenfovasküler invazyon & 17 & 47 \\
\hline Ekstrakapsüler invazyon & 12 & 32 \\
\hline \multicolumn{3}{|l|}{ Grade } \\
\hline I & 24 & 29 \\
\hline II & 34 & 42 \\
\hline III & 24 & 29 \\
\hline \multicolumn{3}{|l|}{ Laboratuvar bulguları } \\
\hline Anemi $(<12 \mathrm{~g} / \mathrm{dL})$ & 60 & 75 \\
\hline $\mathrm{CRP}(>5 \mathrm{mg} / \mathrm{L})$ & 30 & 60 \\
\hline \multicolumn{3}{|l|}{ Evre } \\
\hline Evre I & 7 & 9 \\
\hline Evre II & 21 & 25 \\
\hline Evre III & 22 & 27 \\
\hline Evre IV & 32 & 39 \\
\hline Ortanca tümör çap1 & \multicolumn{2}{|c|}{$3 \mathrm{~cm}(0,3-11 \mathrm{~cm})$} \\
\hline Ortanca tutulan lenf nodu sayısı & $2(1-11)$ & \\
\hline
\end{tabular}

ECOG: Eastern Cooperative Oncology Group, PHP: parahipofarenks, PH: paranazal sinüs, CRP: C-reaktif protein. 
Radyoterapi 38 (\%48) hastaya, kemoradyoterapi 34 (\%42) hastaya uygulanmıştır. Radyoterapi uygulanan hastalardan 36'sında (\%95) kilo kaybı, 34'ünde (\%90) bulantı, kusma ve 34'ünde (\%90) kserostomi en s1k görülen yan etkiler iken, kemoradyoterapi alan hastaların 28'inde (\%82) kilo kaybı, 31'inde (\%91) bulantı, kusma, 34'ünde (\%100) kserostomi, 23'ünde (\%68) grade 1-2 cilt reaksiyonu, 12'sinde (\%62) grade 3-4 mukozit en sik görülen yan etkiler olarak tespit edildi. Kemoradyoterapi alan hastalar ile radyoterapi alan hastalar arasında yan etki sıklığı açısından nötropeni $(p=0,026)$, nötropenik ateş $(\mathrm{p}=0,045)$ ve mukozit $(\mathrm{p}: 0,003)$ gelişimi açısından istatistiksel olarak anlamlı farklılık tespit edildi. Tedaviye bağlı yan etkiler Tablo 3 'te görülmektedir.

Tablo 2. Tek değişkenli analize göre sağkalımı etkileyen prognostik faktörler.

\begin{tabular}{|c|c|c|c|}
\hline Tek değişkenli analiz & Hasta sayısı & 2 yıllık genel sağkalım & $\mathbf{P}$ \\
\hline \multicolumn{4}{|l|}{ Hipertansiyon } \\
\hline Yok & 65 & 65 & \\
\hline Var & 17 & 29 & 0,043 \\
\hline \multicolumn{4}{|l|}{$\begin{array}{l}\text { Performans durumu } \\
\end{array}$} \\
\hline ECOG 0 & 25 & 94 & \\
\hline$\geq$ ECOG 1 & 57 & 43 & 0,003 \\
\hline \multicolumn{4}{|l|}{ Lokalizasyon } \\
\hline Oral kavite & 21 & 52 & \\
\hline PHF ve PN & 8 & 25 & \\
\hline Nazofarenks & 14 & 85 & \\
\hline Larenks & 37 & 62 & 0,002 \\
\hline \multicolumn{4}{|l|}{ Evre } \\
\hline Evre I & 7 & 80 & \\
\hline Evre II & 21 & 74 & \\
\hline Evre III & 22 & 90 & \\
\hline Evre IV & 32 & 24 & 0,001 \\
\hline \multicolumn{4}{|l|}{ T evre } \\
\hline $\mathrm{T} 1$ & 16 & 84 & \\
\hline $\mathrm{T} 2$ & 30 & 64 & \\
\hline $\mathrm{T} 3$ & 14 & 74 & \\
\hline $\mathrm{T} 4$ & 22 & 22 & 0,012 \\
\hline \multicolumn{4}{|l|}{$\mathbf{N}$ evre } \\
\hline N0 & 41 & 67 & \\
\hline N1 & 17 & 73 & \\
\hline $\mathrm{N} 2$ & 24 & 28 & 0,027 \\
\hline \multicolumn{4}{|c|}{ Radyoterapiye ara verilmesi } \\
\hline Yok & 57 & 66 & \\
\hline Var & 20 & 42 & 0,029 \\
\hline \multicolumn{4}{|l|}{ CRP } \\
\hline Normal & 20 & 71 & \\
\hline Yüksek & 30 & 40 & 0,021 \\
\hline \multicolumn{4}{|l|}{ Anemi } \\
\hline Yok & 20 & 41 & \\
\hline Var & 60 & 66 & 0,024 \\
\hline
\end{tabular}


Tablo 3. Radyoterapi/kemoradyoterapinin yan etkileri.

\begin{tabular}{|c|c|c|c|}
\hline \multicolumn{4}{|c|}{ Tedavi akut yan etkileri } \\
\hline & Radyoterapi hasta sayısı (\%) & Kemoradyoterapi hasta sayısı (\%) & $\mathrm{P}$ \\
\hline Anemi & $13(34)$ & $14(41)$ & 0,357 \\
\hline \multicolumn{4}{|l|}{ Trombositopeni } \\
\hline Grade $1-2$ & $2(5)$ & $2(6)$ & \\
\hline Grade 3-4 & 0 & $1(3)$ & 0,561 \\
\hline \multicolumn{4}{|l|}{ Nötropeni } \\
\hline Grade $1-2$ & $4(11)$ & $12(35)$ & \\
\hline Grade 3-4 & $1(3)$ & $2(61)$ & 0,026 \\
\hline Nötropenik ateş & 0 & $4(12)$ & 0,045 \\
\hline \multicolumn{4}{|l|}{ Cilt Reaksiyonu } \\
\hline Grade1-2 & $31(82)$ & $23(68)$ & \\
\hline Grade3-4 & $7(18)$ & $10(30)$ & 0,286 \\
\hline \multicolumn{4}{|l|}{ Mukozit } \\
\hline Grade1-2 & $27(71)$ & $13(38)$ & \\
\hline Grade3-4 & $9(24)$ & $12(62)$ & 0,003 \\
\hline Kilo kayb1 & $36(95)$ & $28(82)$ & 0,098 \\
\hline Bulant1-kusma & $34(90)$ & $31(91)$ & 0,563 \\
\hline \multicolumn{4}{|c|}{ Radyoterapinin geç yan etkileri } \\
\hline Kserostomi & $34(90)$ & $34(100)$ & 0,072 \\
\hline
\end{tabular}

\section{Tartışma}

Baş boyun kanserlerinde, öncelikli olarak hastalıksız bir yaşam ve organların olabildiğince korunduğu fonksiyonel bir sonuç elde etmek amaçlanmaktadır. Cerrahi ve/veya radyoterapi gibi lokal tedavi şekilleri definitif amaçlı tedavi için erken evre hastalıkta tek başına tercih edilirken lokal ileri hastalığı olan hastalarda farklı tedavi yaklaşımları ile lokal bölgesel kontrol oranlarının artırılması ve sağkalım avantajı yakalaması amaçlanmıştır.

Komorbidite, kanser hastasının bakımını, tedavi modalitesinin seçimini ve tedavinin etkisinin değerlendirilmesini doğrudan etkilemektedir. Piccirillo ve ark. [8]'nın yaptıkları çalışmada baş boyun kanserli hastaların \%24'ünde komorbidite varlığ 1 tespit edilmiştir. Primer baş boyun kanserli 1086 hastayla yapılan prospektif bir çalışmada komorbiditenin, yaş, cinsiyet, ırk ve evreden sonra 2 yıllık sağkalımda bağımsız bir prognostik faktör olduğu tespit edilmiştir [9]. Bu çalışmada komorbiditesi olmayan hastalarla, komorbiditesi olan baş boyun kanserli hastalar karşılaştılmış ve komorbidite için mortalite risk oranı (HR) 1,9 olarak bulunmuştur [9]. Çalışmamızdaki hastalarda komorbidite görülme oran1 \%28'di. Komorbid hastalıklar arasında en sık karş1laşılan hipertansiyon idi. Komorbidite varlığının sağkalımı etkilemediği ancak hipertansiyon varlığının sağkalımı istatistiksel olarak anlamlı düzeyde etkilediği belirlendi. 2 yıllık genel sağkalım oranı hipertansiyonu olan hastalarda \%29 ve hipertansiyonu olmayan hastalarda ise \%65'ti.

Rades ve ark. [10]'nın yaptıkları çalışmada baş boyun kanseri için en önemli prognostik faktörlerin rezeksiyon genişliği, radyoterapi öncesi hemoglobin seviyesi, tümör evresi ve performans durumu olduğu bildirilmiştir. Bu çalışmaya göre 2 yıllık sağ kalım oranları T1-2 tümör evresine sahip hastalarda \%86, T3-4 tümör evresine sahip hastalarda ise \%68 olarak belirtilmiştir ( $\mathrm{p}=0.016$ ). Aynı çalışmada 2 yıllık sağkalım oranı evre I-III olan hastalarda \%86, evre IV olan hastalarda \%68 ( $\mathrm{p}=0,037)$, N0-2a nodal evresine sahip hastalarda \%83, N2b-3 nodal evresine sahip hastalarda ise \%67 $(\mathrm{p}=0,06)$ olarak bulunmuştur. Yine bu çalışmada 2 yıllık sağkalım oranı radyoterapi başlangıcındaki hemoglobin düzeylerine göre anemi varlığında $\% 63(\mathrm{p}=0,036)$. Anemisi olmayanlarda ise $\% 88$ 'dir. ECOG performans durumu 0-1 olan hastalarda \%83, ECOG performans durumu 2 olan hastalarda ise $\% 54$ olarak bulunmuştur $(\mathrm{p}=0,001)$ [10]. Çalışmamızda 2 yıllık 
genel sağkalım oranı tümör evresi T1 olan hastalarda \%84, T2 olan hastalarda \%64, T3 olan hastalarda \%74 ve T4 olan hastalarda \%22 olarak bulundu. Baş boyun kanserli hastalarda prognozun tanı sırasında evreyle doğrudan ilişkili olduğu birçok çalışmada belirtilmektedir. Evre I hastalarda 5 yıllık sağkalım \%80 üzerindeyken bu oran evre IV hastalarda \% 40'ın altına düşmektedir [4]. Çalışmamızda evre I, II, III ve IV tümörü olan hastalarda 2 yıllık genel sağkalım oranları sirasıyla \%80, \%74, \%90 ve \%24 olarak bulunmuştur ve ileri evrenin sağkalımı olumsuz yönde etkilediği tespit edilmiştir. Çalışmacılar boyunda metastatik lenf nodu varlığının, sağkalım oranını aynı T evresinde lenf nodu tutulumu olmayanlara kıyasla \%50 azalttığını bildirmişlerdir [11]. Çalışmamızda N0-1-2 nodal evreye sahip hastalarda 2 yıllık genel sağkalım oranları sirasıyla \%67, \%73 ve \%28 olarak bulunmuştur ve lenf nodu metastazının prognozu olumsuz yönde etkilediği belirlenmiştir.

Baş boyun kanserli hastalarda aneminin kötü prognostik faktör olduğu birçok çalışmada gösterilmiştir $[12,13]$. Çalışmamızda radyoterapi başlangıcında anemisi olan hastalarda 2 y1llık genel sağkalım oranı \%41 olarak bulunmuştur ve bunun 2 yıllık genel sağkalımı olumsuz yönde etkilediği tespit edilmiştir. Birçok maligniteye benzer biçimde, baş boyun kanserli hastalarda tedavi öncesi performans durumunun tedavi sonuçlarını etkilediği gösterilmiştir $[12,13]$. Çalışmamızda 2 yıllık genel sağkalım oranının ECOG performans durumu 0 olan hastalarda $\% 94,1$ olan hastalarda ise $\% 41$ olarak bulunmas1 performans durumunun sağkalımı etkilediğini göstermektedir.

Çok sayıda çalışma perinöral invazyonun en önemli kötü prognostik faktör olduğuna işaret etmektedir [5]. Aynı zamanda, baş boyun kanserli hastalarda perinöral invazyon varlığının lejyonal lenf nodu metastaz riskini artırdığı, definitif tedaviden sonra lokorejyonal kontrolü ve tüm sağkalımı olumsuz yönde etkilediği belirlenmiştir [5, 14]. Bazı çalışmalarda ise perinöral invazyonun uzak metastaz riskini artırdığı savunulmuştur [14]. Yılmaz ve ark. [15] perinöral invazyonun boyun metastazı üzerine etkisinin sinırlı olduğunu bildirmişlerdir. Çalışmamızda perinöral invazyonu olan hastalarda 2 yıllık genel sağkalım, perinöral invazyonu olmayan hastalarla eşit oranda bulunmuştur.

Yılmaz ve ark. [15] perivasküler invazyonun lokal ve bölgesel nüksü artırdığını, uzak metastaz riskini etkilemediğini, cerrahi ile nüks arasındaki süreyi belirgin derecede kısalttığını bildirmişlerdir. Ayrıca, perivasküler ve perinöral yayılımın boyun metastazında artışa neden olarak sağkalım ve nüksü etkilediği belirtilmiştir. Çalışmamızda lenfovasküler invazyon tespit edilen hastalarda 2 yıllık genel sağkalım oranı \%57 olarak bulunmuş, lenfovasküler invazyon tespit edilmeyen hastalarla karşılaştırıldığında belirgin farklılık olmadığı saptanmıştır.

Ektrakapsuler invazyonun, hastalıksız sağkalım ve tüm sağkalım için belirgin bir prognostik faktör olduğu birçok çalışmada belirtilmektedir. Nicolai ve ark. [16]'nın yaptıkları retrospektif bir çalışmada cerrahi ve postoperatif radyoterapi ve tek başına cerrahi ile tedavi edilen baş boyun kanserli 281 hasta değerlendirilmiştir. Beş yıllık sağkalım N0 hastalarda \%65, ekstrakapsüler invazyonu olmayan nod tutulumu olan hastalarda $\% 49$ ve ekstrakapsüler invazyonu olan ve nod tutulumu olan hastalarda ise $\% 20$ olarak bulunmuştur [16]. Bu verilere göre, ekstrakapsüler invazyon pozitifliğinin de sağkalımı olumsuz yönde etkilediği düşünülmektedir. Çalışmamızda ektrakapsüler invazyon tutulumu sadece cerrahi yapılmış hastalarda gösterilmiştir. Ekstrakapsüler invazyon durumu belli olan hastalar için ekstrakapsüler invazyonun pozitif olması sağkalımı olumsuz olarak etkilememekteydi. Bu sonuç muhtemelen hastaların büyük çoğunluğunda ekstrakapsüler invazyon durumunun belli olmamasıyla ilişkili olabilir.

Khandavilli ve ark. [17] serum CRP seviyesinin oral skuamoz hücreli karsinomlu hastalarda bağımsız prognostik bir faktör olduğunu belirtmişlerdir. Çalışmalarında 2 yıllık sağkalım oranı CRP seviyesi normal olan hastalarda \%90, CRP seviyesi yüksek olan hastalarda ise \%44 olarak bulunmuştur, bu bulgu istatistiksel olarak anlaml bulunmuştur ( $\mathrm{p}=0,003$ ). Çalışmamızda 2 yıllık genel sağkalım oranı CRP seviyesi normal olan hastalarda \%71, CRP seviyesi yüksek olan hastalarda ise \%40 olarak bulundu. Bu 
sonuca göre tedavi başlangicındaki serum CRP seviyesinin prognozu etkilediği tespit edildi. Tedavi süresi fraksiyon boyutuna, klinik şartlarına (tedavi cihazı arızası gibi), toksisite nedeniyle tedaviye ara verilmesine ve hastanın sosyo-kültürel ve ekonomik şartlarına göre değişebilmektedir. Fowler ve ark. [18]'nın yaptıkları bir metaanalizde tedavi süresinde bir haftalık uzamanın lokal kontrolü medyan \% 14 (3-25) oranında azalttığı belirtilmiştir. Yapılan bir diğer çalışmada da tedaviye 5 gün veya daha fazla ara verilmesinin hem lokal-bölgesel kontrolü hem de hastalığa özgü sağkalımı anlamlı olarak azalttığı bulunmuştur [19]. Çalışmamızda da 2 yıllık genel sağkalım yan etki nedeniyle radyoterapiye ara verilen hastalarda $\% 42$, radyoterapiye ara verilmeyen hastalarda ise \%66 olarak bulundu. Bu sonuç tedaviye ara verilmesinin tedavi başarısını azalttığını ve sağkalımı etkileyen prognostik bir faktör olduğunu göstermiştir.

Starr ve ark. [20] kemoradyoterapi ile tedavi edilen hastalarda daha fazla çiğneme güçlüğü ve sürekli beslenme tüpü gereksinimi olduğunu bildirmişlerdir. Başka bir çalışmada ise kemoradyoterapi ile tedavi edilen hastaların tümünde oral beslenme ürünü veya parenteral destek tedavi gereksiniminin ortaya çıktığı ve hastaların \%10'una hospitalizasyon gerektiği ifade edilmiştir [21]. Kemoradyoterapi alan hastalarda Lee ve ark. [22] \%32, Chan ve ark. [23] \%74, Wee ve ark. [24] \%12, Cheng ve ark. [25] ise \%25 oranında kilo kaybı bildirmişlerdir. Çalışmamızda tedavi modalitelerine göre kilo kaybı gelişimi değerlendirilmiş olup radyoterapi alan hastaların \%95, kemoradyoterapi alan hastaların ise \%82'sinde kilo kaybı tespit edilmiş olup, bu oran diğer çalışmalara göre oldukça yüksek bulunmuştur. Ancak, tedavi modaliteleri arasında kilo kaybı açısından fark görülmemiştir. Hastaların çoğunda başlangıçtan itibaren kilo kaybının olması ve tedavi süresince beslenme güçlügünün de eklenmesiyle kilo kaybının artabileceği göz önüne alındığında, hastaların tedaviye başlamadan önce beslenme desteği ve gastrostomi gereği için değerlendirilmesi uygun olacaktır. Böylece hastalarda yeterli beslenme desteği sağlanıp yan etkiler azaltılarak hastaların tedaviye uyumu artırılmış olacaktır. Çalışmamızda ayrıca kemoradyoterapi ve radyoterapi alan hastalarda nötropeni, nötropenik ateş ve mukozit yan etkilerinin daha sık görüldüğü tespit edilmiştir.

Özellikle 5-Fluorourasil ile yapilan kemoradyoterapi tedavilerinde grade 3 ve üzeri mukozit yan etkisi riskinin arttı̆g (\%98 gibi yüksek oranlarda), bununla birlikte, 3 yıllık genel sağkalım oranının da \%40'lardan \%60-70'lere yükseldiği gösterilmiştir [26, 27]. Bernier ve ark. [28] ve Cooper ve ark. [29] cisplatinle eş zamanlı uygulanan kemoradyoterapi ile grade 3 ve 4 mukozit oranlarının tek başına uygulanan radyoterapiye göre iki kat fazla olduğu ve ölüm riskinde de \%2'lik bir atış ile ilişkili olduğu bulunmuştur. Bonner ve ark. [30] da kemoradyoterapinin mukozit, beslenme tüpü bağımlılı̆̆1, dermatit, hematolojik süpresyon ve enfeksiyon riskini artırdığını bildirmişlerdir. Çalışmamızda kemoradyoterapi yapılan hastaların \%38'inde grade 1-2, $\% 62$ 'sinde grade 3-4 mukozit tespit edildi. Bununla birlikte, sadece radyoterapi yapilan hastalarda grade 1-2 mukozit oran1 \%71, grade 3-4 mukozit oran1 \%24 olup aradaki farklılık istatistiksel olarak anlamlı idi. Mukozit gelişiminin tedaviye ara verilmesinde en önemli neden olduğu ve tedaviye ara verilmesinin de tümör kontrolünde azalmaya yol açtığı düşünülürse hastaların oral hijyeninin sağlanması ve yan etkilerin yakın takip edilmesinin hastaların tedaviye uyumunu artıracağı kanısındayız.

Çalışmamızda tek değişkenli analizde, kanser lokalizasyonu, anemi varlığı, CRP düzeyi, yan etki nedeniyle radyoterapiye ara verilmesi, ECOG performans durumu, T ve $\mathrm{N}$ evresi, tümör evresi ve eşlik eden hipertansiyon varlığı hastaların sağkalımını etkileyen prognostik faktörler olarak belirlendi. Tedavi planlaması yapılırken ve tedavi etkinliğini artırmak için gerek hastaya gerekse hastalığa ait prognostik faktörlerin bilinmesi büyük önem taşımaktadır.

\section{Kaynaklar}

1. Jemal A, Murray T, Samuels A, Ghafoor A, Ward E, Thun MJ. Cancer Statistics, 2003. CA Cancer J Clin 2003; 53: 5-26.

2. Öztop İ. Baş-boyun tümörlerinde hedefe yönelik tedavi. Uluslararası Hematoloji- 
Onkoloji Dergisi 2008; 1: 46-56.

3. Kamangar F, Dores GM, Anderson WF. Patterns of cancer incidence, mortality, and prevalence across five continents: defining priorities to reduce cancer disparities in different geographic regions of the world. J Clin Oncol 2006; 24 : 2137-50.

4. Aydıner A, Topuz E. Onkoloji El Kitabı. In: Uslu R, Bilgen C, Esassolak M. Baş ve boyun kanserleri. 1. bask1. İstanbul: Turgut Yayıncıl1k 2006; pp: 81-115.

5. Harrison, Louis B, Roy B, Houng, Waun KI. Head and Neck Cancer: A Multidisciplinary Approach. In: Smith BD, Haffty BG. Prognostic Factors in Patients with Head and Neck Cancer. 3rd edition. Philadelphia: Lippincott Williams \& Wilkins 2009; pp: 52-70.

6. Greene FL, Page DL, Fleming ID, Fritz A, Balch CM, Haller DG, Morrow M. AJCC Cancer Staging Handbook. In: TNM classification of malignant tumours. 6th ed. New York:Springer-Verlag; 2002

7. National Cancer Institute. Cancer Therapy Evaluation Program Common Toxicity Criteria Manuel, Version 2.0

8. Piccirillo JF, Tierney RM, Costas I, Grove L, Spitznagel EL Jr. Prognostic importance of comorbidity in a hospital-based cancer registry. JAMA 2004; 291: 2441-47.

9. Reid BC, Alberg AJ, Klassen AC, Samet JM, Rozier RG, Garcia I, Winn DM. Comorbidity and survival of elderly head and neck carcinoma patients. Cancer 2001; 92: 2109-16.

10. Rades D, Fehlauer F, Wroblesky J, Albers D, Schild SE, Schmidt R. Prognostic factors in head-and-neck cancer patients treated with surgery followed by intensity-modulated radiotherapy (IMRT), 3D-conformal radiotherapy, or conventional radiotherapy. Oral Oncol 2007; 43: 535-43.

11. Abraham J, Allegra CJ, Gulley J. Klinik Onkolji El Kitabı. In: Conley BA, Forastiere AA, Gius D, VanWaes C. Baş Boyun. Çeviri Editörü Alpaslan Mayadağl1, Cem Parlak.1.bask1. İstanbul: Nobel T1p Kitabevi 2009; s: 3-31.

12. Prosnitz RG, Yao B, Farrell CL, Clough R, Brizel DM. Pretreatment anemia is correlated with the reduced effectiveness of radiation and concurrent chemotherapy in advanced head and neck cancer. Int J Radiat Oncol Biol Phys 2005; 61: 1087-95.

13. Brizel DM, Albers ME, Fisher SR, Scher RL, Richtsmeier WJ, Hars V, George SL, Huang AT, Prosnitz LR. Hyperfractionated irradiation with or without concurrent chemotherapy for locally advanced head and neck cancer. N Engl J Med 1998; 338: 1798-804.

14. Rahima B, Shingaki S, Nagata M, Saito C. Prognostic significance of perineural invasion in oral and oropharyngeal carcinoma. Oral Surg Oral Med Oral Pathol Oral Radiol Endod 2004; 97: 423-31.

15. Yılmaz T, Hosal AS, Gedikoğlu G, Önerci M, Gürsel B. Prognostic significance of vascular and perineural invasion in cancer of the larynx. Am J Otolaryngol 1998; 19: 83-8.

16. Nicolai P, Redaelli de Zinis LO, Tomenzoli D, Barezzani MG, Bertoni F, Bignardi M, Antonelli AR. Prognostic determinants in supraglottic carcinoma: univariate and Cox regression analysis. Head Neck 1997; 19: 323-34.

17. Khandavilli SD, Ceallaigh PO, Lloyd CJ, Whitaker R. Serum C-reactive protein as a prognostic indicator in patients with oral squamous cell carcinoma. Oral Oncol 2009; 45: 912-4.

18. Fowler JF, Lindstrom MJ. Loss of local control with prolongation in radiotherapy. Int J Radiat Oncol Biol Phys 1992; 23: 457-67.

19. Meydan D, Gürsel B, Şahin N, Özbek N. Erken evre glottik larenks kanserinde radyoterapi sonuçları: Tek merkez deneyimi. Deneysel ve Klinik Tıp Dergisi 2012; 29: 141-7.

20. Staar S, Rudat V, Stuetzer H, Dietz A, Volling P, Schroeder M, Flentje M, Eckel 
HE, Mueller RP. Intensified hyperfractionated accelerated radiotherapy limits the additional benefit of simultaneous chemotherapy--results of a multicentric randomized German trial in advanced head-and-neck cancer. Int J Radiat Oncol Biol Phys 2001; 50: 1161-71.

21. Akman F. Yerel ileri baş-boyun kanserlerinde kemoradyoterapi. Turkiye Klinikleri J Med Oncol-Special Topics 2010; 3: 36-40.

22. Lee AW, Lau WH, Tung SY, Chua DT, Chappell R, Xu L, Siu L, Sze WM, Leung TW, Sham JS, Ngan RK, Law SC, Yau TK, Au JS, O'Sullivan B, Pang ES, O SK, Au GK, Lau JT; Hong Kong Nasopharyngeal Cancer Study Group. Preliminary results of a randomized study on therapeutic gain by concurrent chemotherapy for regionally-advanced nasopharyngeal carcinoma: NPC-9901 Trial by the Hong Kong Nasopharyngeal Cancer Study Group. J Clin Oncol 2005; 23: 6966-75.

23. Chan AT, Teo PM, Ngan RK, Leung TW, Lau WH, Zee B, Leung SF, Cheung FY, Yeo W, Yiu HH, Yu KH, Chiu KW, Chan DT, Mok T, Yuen KT, Mo F, Lai $\mathrm{M}$, Kwan WH, Choi P, Johnson PJ. Concurrent chemotherapy-radiotherapy compared with radiotherapy alone in locoregionally advanced nasopharyngeal carcinoma: progression-free survival analysis of a phase III randomized trial. J Clin Oncol 2002; 20: 2038-44.

24. Wee J, Tan EH, Tai BC, Wong HB, Leong SS, Tan T, Chua ET, Yang E, Lee KM, Fong KW, Tan HS, Lee KS, Loong S, Sethi V, Chua EJ, Machin D. Randomized trial of radiotherapy versus concurrent chemoradiotherapy followed by adjuvant chemotherapy in patients with American Joint Committee on Cancer/International Union against cancer stage III and IV nasopharyngeal cancer of the endemic variety. J Clin Oncol 2005; 23: 6730-8.

25. Cheng SH, Tsai SY, Yen KL, Jian JJ, Chu NM, Chan KY, Tan TD, Cheng JC, Hsieh CY, Huang AT. Concomitant radiotherapy and chemotherapy for earlystage nasopharyngeal carcinoma. J Clin Oncol 2000; 18: 2040-5.

26. Machtay M, Rosenthal DI, Hershock D, Jones H, Williamson S, Greenberg MJ, Weinstein GS, Aviles VM, Chalian AA, Weber RS; Penn Cancer Center Clinical Trials Group. Organ preservation therapy using induction plus concurrent chemoradiation for advanced resectable oropharyngeal carcinoma: A University of Pennsylvania Phase II Trial. J Clin Oncol 2002; 20: 3964-71.

27. Adelstein DJ, Saxton JP, Lavertu P, Rybicki LA, Esclamado RM, Wood BG, Strome M, Carroll MA. Maximizing local control and organ preservation in stage IV squamous cell head and neck cancer With hyperfractionated radiation and concurrent chemotherapy. J Clin Oncol 2002; 20:1405-10.

28. Cooper JS, Pajak TF, Forastiere AA, Jacobs J, Campbell BH, Saxman SB, Kish JA, Kim HE, Cmelak AJ, Rotman M, Machtay M, Ensley JF, Chao KS, Schultz CJ, Lee N, Fu KK; Radiation Therapy Oncology Group 9501/Intergroup. Postoperative concurrent radiotherapy and chemotherapy for high-risk squamouscell carcinoma of the head and neck. N Engl J Med 2004; 350: 1937-44.

29. Bernier J, Domenge C, Ozsahin M, Matuszewska K, Lefèbvre JL, Greiner RH, Giralt J, Maingon P, Rolland F, Bolla M, Cognetti F, Bourhis J, Kirkpatrick A, van Glabbeke M; European Organization for Research and Treatment of Cancer Trial 22931. Postoperative irradiation with or without concomitant chemotherapy for locally advanced head and neck cancer. N Engl J Med 2004; 350: 1945-52.

30. Bonner JA, Harari PM, Giralt J, Azarnia N, Shin DM, Cohen RB, Jones CU, Sur R, Raben D, Jassem J, Ove R, Kies MS, Baselga J, Youssoufian H, Amellal N, Rowinsky EK, Ang KK. Radiotherapy plus cetuximab for squamous-cell carcinoma of the head and neck. N Engl J Med 2006; 354: 567-78. 